\title{
Nova Redenção: uma ruralidade amazônica
}

\section{Nova Redenção: An Amazon Rurality}

Voyner Ravena Cañete - Antropóloga, Professora do Programa de Pós-Graduação em Ecologia Aquática e Pesca (PPGEAP) e do Programa de Pós-Graduação em Ciências Sociais (PPGCS), ambos da Universidade Federal do Pará - UFPA. E-mail: ravenacanete@ufpa.br

\section{Resumo}

No decorrer das últimas três décadas o crescimento do setor agrário brasileiro trouxe consigo variações para o modo de vida rural do país. Na Amazônia, esse movimento de transformação encontra-se em processo acelerado e vem produzindo impactos e modificando o cotidiano das populações rurais da região. Compreendendo a ruralidade como um valor social, este artigo descreve Nova Redenção, localidade típica do nordeste paraense, e parte do cotidiano agrícola de seus moradores, caracterizando ainda o objeto de estudo a partir do debate sobre a produção agrícola familiar e seu futuro nas sociedades industriais.

\begin{abstract}
Throughout the past three decades, growth in Brazilian agricultural sector has entailed changes in local rural ways of living. In the Amazon, rapid increase of such transformations has had profound impact on the everyday life of rural populations. Regarding rurality as a social value, the present paper describes Nova Redenção, a typical village in the Northeast of Pará, and the agricultural everyday life of its dwellers. The object of study is also characterized with regard to the debate over family agricultural production and its future in industrial societies.
\end{abstract}

\section{Palavras-chave}

Campesinato. Amazônia. Ruralidade.

\section{Keywords}

Peasantry. Amazon. Rurality. 


\section{INTRODUÇÃO}

Os estudos das Ciências Sociais têm demonstrado como a valorização das regiões rurais tem de fato orientado o movimento geral da sociedade moderna. $\mathrm{O}$ meio rural corresponde a $1 / 4$ da população dos países ricos e talvez em proporções maiores nos países em desenvolvimento (ABRAMOVAY, 2003, p. 11-13; VEIGA, 2002). Nestes, especialmente o mundo rural não se restringe apenas à produção agrícola, mas se estende a um leque variado de atividades relacionadas a serviços e comércio, formando assim um cenário diverso, bem diferente do imaginário presente no senso comum que vê a área rural composta apenas por atividades diretamente relacionadas à agricultura.

Um dos movimentos que contribuiu fortemente para a nova conformação do meio rural está relacionado à transferência pública de renda para essa área, permitindo a ampliação das atividades econômicas nela contidas. O fornecimento de matéria-prima como característica prioritária do meio rural é cada vez menos importante, pois novos fatores são incorporados na definição da ruralidade. Planejamento governamental, multifuncionalidade, multiplicidade de atores sociais, entre outros fatores que envolvem a formação do rural, permeiam vários trabalhos nas Ciências Sociais. De toda forma, o consenso presente nessa discussão relacionase à compreensão de que agricultura, indústria e comércio são setores econômicos, enquanto ruralidade se constitui em valor ao qual o mundo contemporâneo atribui constante importância (ABRAMOVAY, 1992, 2003).

Portanto, ao se lançar o olhar para o rural não se deve considerar apenas a produção agrícola que ainda o caracteriza, mas pensar outras atividades que estão nele presentes e que estabelecem relações com a sociedade maior. Na Amazônia, área de fronteira nos últimos 30 anos, as transformações do campo rural estão cada vez mais intensas e, em decorrência desse novo quadro em constante movimento, pensar novas práticas dentro de seu meio transformou-se em reflexão obrigatória para sua compreensão. A mobilidade entre campo e cidade que caracteriza a população rural dessa área do país constituiu-se em situação permissiva para uma transformação mais rápida. Ao mesmo tempo a inserção cada vez mais intensa da pecuária extensiva na região reforça as condições para mudança. A monocultura especializada, centrada na soja no sul do Pará, por exemplo, constitui-se em novo cenário a ser compreendido. Neste, práticas antigas cedem lugar a novas formas de reprodução material e social, sendo que o reflexo desse novo contexto afeta 
frontalmente as populações tradicionais. Refletir sobre esse processo significa pensar mudança e movimento.

Este trabalho focaliza Nova Redenção, localidade situada na zona rural de Concórdia do Pará, município do nordeste paraense, distante $160 \mathrm{~km}$ da capital do estado. Composta totalmente por agricultores, Nova Redenção é marcada por uma lógica camponesa representando uma localidade típica do cenário amazônico. A produção para subsistência e mesmo a pequena produção constituem-se como os elementos-chave que orientam a lógica da reprodução de seus moradores. Possuindo fortes relações com a sociedade do entorno, tanto pelo contato com o mercado através da produção de farinha como pela sazonalidade das atividades econômicas de alguns de seus moradores, a lógica camponesa permanece orientando o cotidiano de seus integrantes.

Dividido em cinco seções, nas quatro primeiras, este artigo descreve Nova Redenção a partir do conceito de ruralidade, campesinato e agricultura familiar, mostrando como na localidade se reproduz um campesinato específico. $\mathrm{Na}$ última seção, discutem-se as teorias que marcaram a definição de campesinato, apontando como podem ser um instrumento analítico na compreensão de Nova Redenção.

\section{NOVA REDENÇÃO}

Nova Redenção é uma localidade com 183 moradores, situada na área rural do município de Concórdia do Pará, distante aproximadamente $200 \mathrm{~km}$ de Belém, capital do estado. Originada pela divisão do município de Bujaru no decorrer da década de 1980, Concórdia do Pará apresenta um quadro precário de infraestrutura urbana e de serviços, a economia do município ainda hoje é sustentada principalmente pelas atividades ligadas à extração da madeira, a uma pecuária extensiva, e à produção agrícola dominada por culturas de subsistência. Todavia, o cultivo da pimenta-do-reino foi introduzido com êxito pelos imigrantes japoneses na região ${ }^{1}$, colocando Concórdia do Pará atualmente entre os maiores produtores de pimenta do estado (IBGE, 2003). A maior parte dos pequenos

\footnotetext{
1 A imigração japonesa no Pará concentra-se especialmente na cidade de Tomé-Açu, distante $70 \mathrm{~km}$ de Concórdia do Pará. Sua influência na microrregião da qual faz parte a cidade é grande e movimenta parte da economia local. Homma (2003) situa a chegada dos primeiros japoneses na Amazônia.
} 
agricultores da região ainda está ligada, no entanto, à produção da farinha, que é vendida nas cidades mais próximas ou levada para Belém.

Concórdia do Pará faz parte da microrregião de Tomé-Açu, que resulta do desmembramento da antiga Zona Guajarina, formada até final da década de 1980 pelos municípios de São Domingos do Capim, Paragominas, Moju, Acará, Capitão-Poço, Tomé-Açu, Irituia, Ourém, Bujaru, Igarapé-Miri, Abaetetuba, Barcarena e São Miguel do Guamá. Alguns municípios remontam seu surgimento ao século XVIII, como é o caso de Barcarena, Igarapé-Miri, São Miguel do Guamá e mesmo Bujaru, cidade a qual pertencia Nova Redenção antes da nova divisão fisiográfica da década de 1990, e da criação do município de Concórdia do Pará, em 1988, como já mencionado. Outras cidades como Tomé-Açu, Capitão-Poço e Paragominas, por exemplo, resultaram do processo de subdivisão de municípios paraenses ocorrido entre as décadas de cinquenta e sessenta do século XX.

Distante $11 \mathrm{~km}$ da sede de Concórdia do Pará, atrás da PA-140, Nova Redenção está contida nos primeiros $5 \mathrm{~km}$ do ramal que corta os terrenos de seus moradores. O povoado central é conhecido como quadro ou vila e está localizado no segundo quilômetro do ramal. Composto por um conjunto de 35 casas ordenadas ao redor do igarapé principal, o quadro abriga ainda a escola que atende às crianças da localidade, assim como a igreja evangélica frequentada pela maior parte de seus moradores. Toda a vila está rodeada por capoeirões ${ }^{2}$ e os igarapés representam um recurso de fundamental importância, pois neles se realiza grande parte das tarefas domésticas e dos trabalhos vinculados à produção da farinha. Após Nova Redenção, o ramal continua até chegar à estrada que segue para Tomé-Açu (Figura 1).

2 Denominação local para vegetação densa. 
Figura 1 - Croqui de localização de Nova Redenção a partir da PA-140.

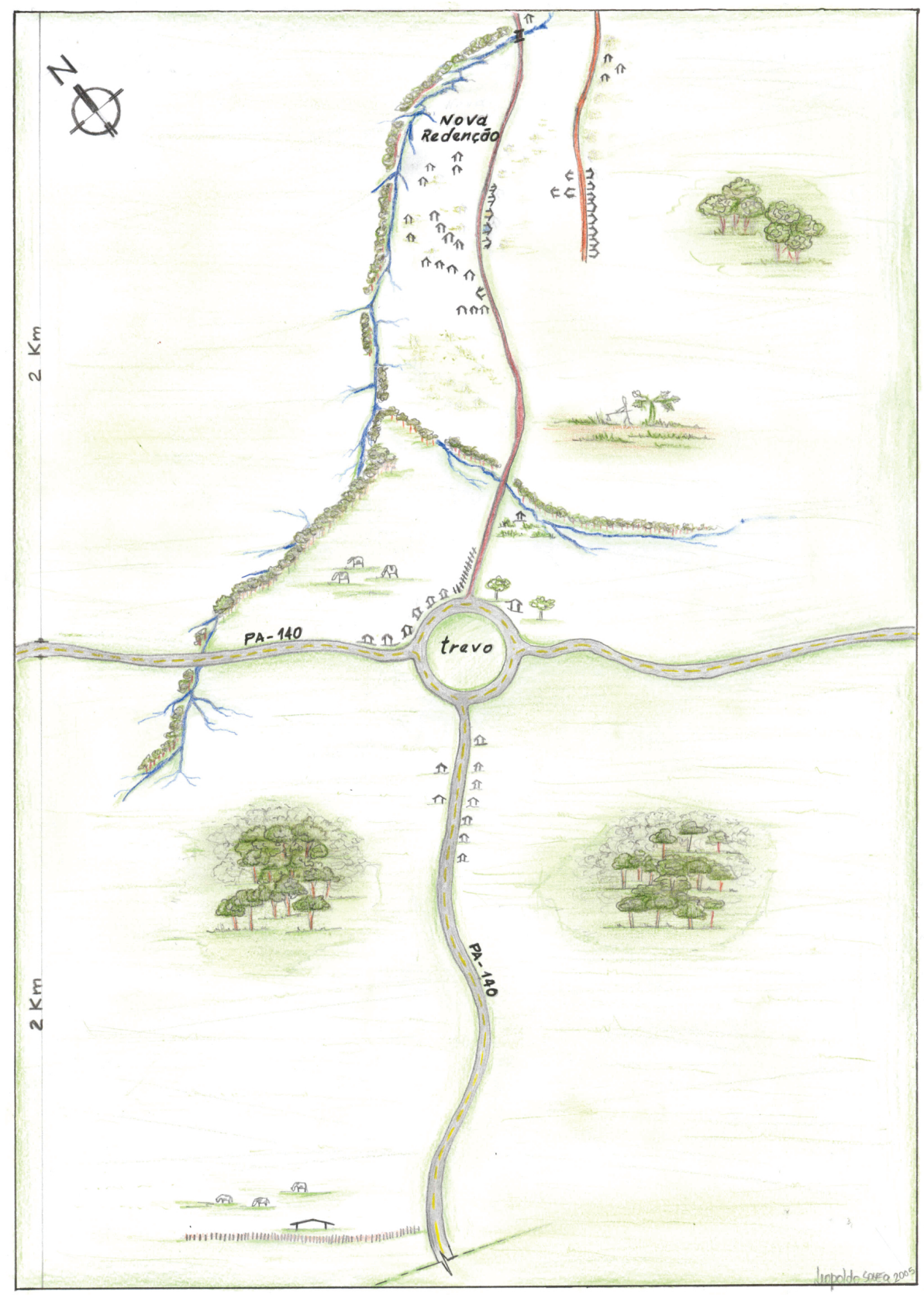

Fonte: Pesquisa de campo (2004). 
O ramal dá acesso aos retiros (casas de farinha), roças e demais habitações que formam o lugar. Além de caminho, o ramal configura-se também como um ponto identificador do território de Nova Redenção e define quem são seus moradores, já que fazer parte da localidade significa ser usuário do ramal para chegar à PA-140. Há outros ramais vizinhos que também dão acesso à rodovia e funcionam como referência para a divisão geopolítica dos vilarejos. Os ramais desempenham, assim, um importante papel na definição das identidades locais. É o fato de usar uma mesma via de acesso à PA-140 que identifica os indivíduos como pertencentes a um mesmo povoado. Compartilhar um caminho para chegar às suas casas possibilita um contato mais próximo entre as pessoas, intensificando as relações sociais e delineando os elementos que constituem as condições necessárias para construção da identidade de um grupo ${ }^{3}$.

Os igarapés configuram-se também como um componente identificador. A localização das famílias é definida pelo "porto" nos quais as atividades domésticas são realizadas. Lavar roupa e louça corresponde a uma atividade normalmente realizada em grupo e representa uma oportunidade de reforçar laços de sociabilidade entre os moradores. Por outro lado, os igarapés representam um referencial importante entre os moradores mais velhos, já que esses cursos d'água foram o único meio de transporte para escoar a produção da área até início da década de $1970^{4}$.

O deslocamento dos moradores de Nova Redenção para Concórdia do Pará é feito por meio dos ônibus, micro-ônibus e vans ${ }^{5}$, que passam em períodos intercalados de uma ou duas horas e percorrendo os $11 \mathrm{~km}$ que separam Nova Redenção do centro da cidade. Com o aumento da extração de madeira na década de 1980 e a emancipação de Concórdia do Pará em 1988, houve uma aceleração do processo de urbanização e, em consequência, o aparecimento e crescimento de serviços públicos como educação, saúde, telefonia e serviços bancários oferecidos à população (IDESP, 1990) antes inexistentes, além da intensificação e diversificação do comércio na cidade. Os serviços prestados pelo posto de saúde no centro da

3 É possível perceber uma identidade contrastiva, já que sair por um ramal significa fazer uma escolha que nega outra, como apontado Oliveira: "Quando uma pessoa ou grupo se afirma como tal, o fazem como meio de diferenciação em relação a alguma pessoa ou grupo com que se defrontam. É uma identidade que surge por oposição" (OLIVEIRA, 1976, p. 5).

4 Em estudo sobre territórios quilombolas no município de Bujaru, Edna Castro aponta os igarapés enquanto componente delimitador do território entre remanescentes de quilombo: "A dimensão territorial se expressa nas narrativas sobre a experiência cotidiana. Os lugares estão referidos aos marcos naturais, sendo os rios e os igarapés, a várzea ou o igapó, as referências principais na demarcação dos espaços" (CASTRO, 2003, p. 22).

5 Automóveis estabelecidos em caráter legal como transporte alternativo às grandes empresas de ônibus que fazem a linha intermunicipal Belém/Tomé-Açu/Belém. 
cidade constituem a maior demanda dos moradores de Nova Redenção, seguida do comércio. É em Concórdia do Pará que os moradores de Nova Redenção compram mantimentos básicos. Margarina, óleo, sabão, laticínios baratos e charque são os itens mais comprados no comércio, seguidos de confecção, instrumentos para as atividades agrícolas, entre outros.

Em Nova Redenção há somente uma escola primária, situada no quadro, na qual quatro turmas são divididas em apenas uma sala. Para os que passam para a $5^{a}$ série do ensino fundamental é necessário ir estudar em Concórdia do Pará. Há um ônibus disponibilizado pela Prefeitura do município que diariamente passa no trevo, fazendo o percurso da PA-140, levando os alunos da área rural para as escolas no centro da cidade. No entanto, a maior parte das crianças sequer termina a $4^{a}$ série do ensino fundamental. Diferentemente de outras populações rurais, em Nova Redenção, continuar os estudos é mais uma opção do grupo para solucionar as pressões da herança sobre a terra do que um ideal de vida. $\mathrm{O}$ estudo é desejável quando se sai da localidade para viver em área urbana, mas não quando se permanece reproduzindo o modo de vida camponês. Assim, famílias com muitos integrantes buscam encaminhar suas filhas para Belém à procura de trabalho doméstico "em casa de família" e seguir estudando. Essa é a alternativa por excelência para não sobrecarregar a demanda local por terra. No caso dos descendentes masculinos, as famílias eventualmente encaminham os filhos para trabalho assalariado ou para se empregar em trabalhos ocasionais nas cidades mais próximas ou mesmo na capital. Para a maioria dos moradores, o ideal é permanecer em Nova Redenção e trabalhar a terra herdada. A permanência na localidade é também motivada pelo interesse em receber os benefícios que o governo concede aos trabalhadores rurais. É muito comum encontrar antigos moradores que retornam a Nova Redenção para assim poderem pleitear a aposentadoria rural. Com isso, observa-se um volume elevado de transferência de renda pública para a localidade.

\section{OS COLONOS DE NOVA REDENÇÃO}

Os moradores de Nova Redenção se autodenominam colonos. Tal definição aparece de forma generalizada na população local e advém, provavelmente, de um processo histórico. A colonização da Amazônia e as políticas governamentais que fundamentaram esse processo podem justificar essa designação, pois a Zona Guajarina sucedeu à colonização da Zona Bragantina ${ }^{6}$.

6 Consultar Hébette e Acevedo (1979a; 1979b), Hébette (1992), Santos (1980). 
Colonos são aqueles que trabalham em pequenas parcelas de terra ${ }^{7}$ e que possuem uma roça de subsistência ${ }^{8}$, ainda que produzindo farinha para a venda e realizando trabalhos sazonais nos pimentais mais próximos ou outro trabalho remunerado. Dos 30 grupos domésticos que compõem Nova Redenção, 28, de alguma forma, fazem o plantio de subsistência, seja nas terras dos pais, seja na forma de a meia ${ }^{9}$ em terras de outros. Mesmo os grupos domésticos que têm no trabalho assalariado seu principal meio de sobrevivência, realizam atividades na roça através do trabalho marcado pela reciprocidade que se expressa nas relações de parentesco. Nos dados que se seguem é possível visualizar a distribuição da população de Nova Redenção por faixa etária e sexo.

Tabela 1 - Moradores de Nova Redenção por faixa etária e sexo ${ }^{10}$

\begin{tabular}{l|c|c|c|c|c|c}
\hline \multicolumn{1}{c|}{ Faixa etária } & Masculino & $\mathbf{\%}$ & Feminino & $\mathbf{\%}$ & Total & $\mathbf{\%}$ \\
\hline 0 a 10 & 19 & 18,25 & 25 & 31,65 & 44 & 24,05 \\
\hline 11 a 19 & 24 & 23,10 & 17 & 21,50 & 41 & 22,40 \\
\hline 20 a 29 & 29 & 27,90 & 14 & 17,70 & 43 & 23,50 \\
\hline 30 a 39 & 09 & 8,65 & 04 & 5,05 & 13 & 7,10 \\
\hline 40 a 49 & 05 & 4,80 & 06 & 7,60 & 11 & 6,00 \\
\hline 50 a 59 & 06 & 5,75 & 08 & 10,15 & 14 & 7,65 \\
\hline 60 a 69 & 06 & 5,75 & 03 & 3,80 & 09 & 4,90 \\
\hline 70 ou mais & 03 & 2,90 & 02 & 2,55 & 05 & 2,75 \\
\hline Idade ignorada & 03 & 2,90 & - & - & 03 & 1,65 \\
\hline Total & $\mathbf{1 0 4}$ & $\mathbf{1 0 0}$ & $\mathbf{7 9}$ & $\mathbf{1 0 0} \%$ & $\mathbf{1 8 3}$ & $\mathbf{1 0 0} \%$ \\
\hline
\end{tabular}

Fonte: Pesquisa de campo (2004).

\footnotetext{
7. A definição para pequeno produtor varia no decorrer da história fundiária na Amazônia. A inferência feita neste trabalho sobre a região advém das informações do Incra sobre os projetos fundiários para a área em questão. Estes classificam os moradores das colônias como pequenos produtores.

8 Entende-se aqui como roça de subsistência as plantações de culturas para consumo do grupo doméstico.

9 Parte dos grupos domésticos que compõem Nova Redenção trabalham no sistema de meia, ou seja, realizam o plantio no terreno de outras pessoas e recebem parte da colheita.

10 Para a população da localidade foram contabilizados apenas os moradores das casas que apresentam condição de moradia permanentemente em Nova Redenção.
} 
Gráfico 2 - Moradores de Nova Redenção por faixa etária e sexo.

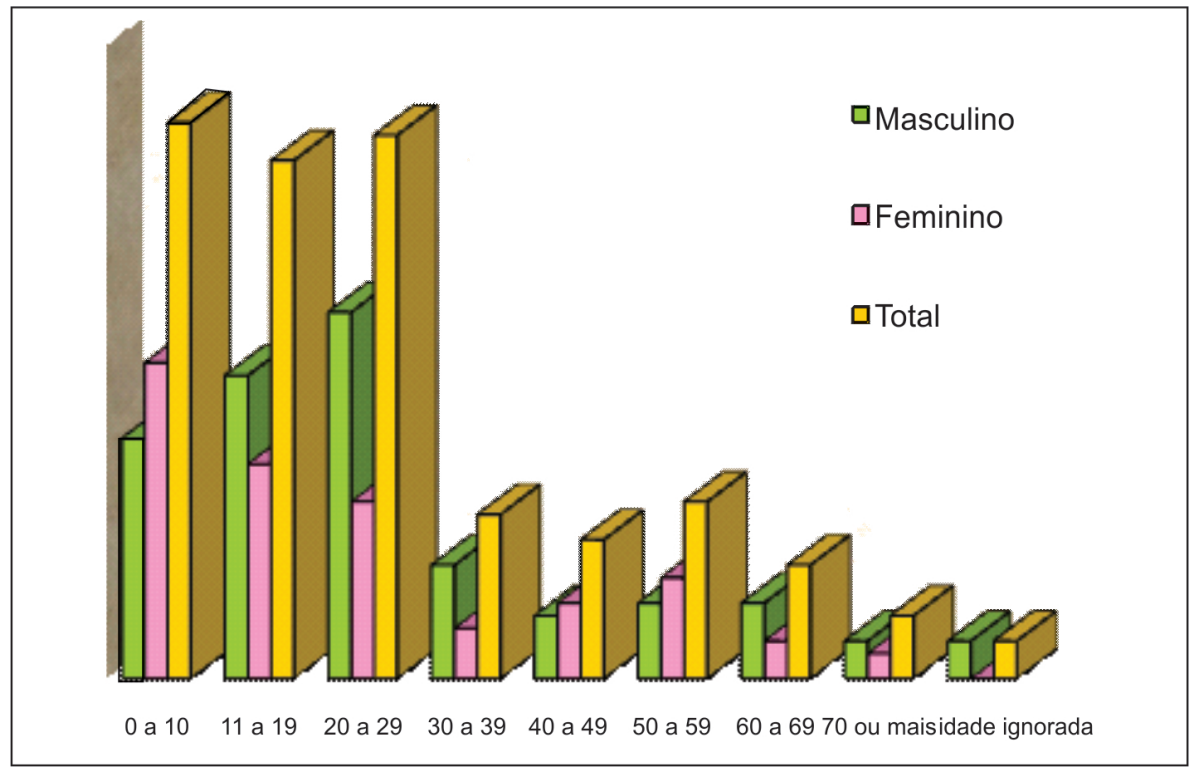

Fonte: Pesquisa de campo (2004)

$\mathrm{Na}$ Figura 2 destaca-se uma população jovem. Aproximadamente $70 \%$ dos moradores estão abaixo da faixa dos 30 anos. Existem mais homens que mulheres, o que confirma a preferência das famílias pela figura feminina para sair da localidade. O total de moradores de Nova Redenção pode ser ainda maior do que o total apresentado na Tabela 2, já que todos os grupos domésticos apresentam integrantes que vivem fora da localidade, mas que podem voltar a viver no lugar se assim o desejarem. A possibilidade de retornar ao grupo é grande e está normalmente relacionada à herança. Um filho pode retomar sua posição de herdeiro, desde que seu pai ainda esteja vivo quando de sua volta para o lugar. Os integrantes que constam da tabela correspondem àqueles que aparecem em uma posição de sazonalidade, ou seja, com frequência retornam a Nova Redenção para permanecer no povoado enquanto assim desejem. Dessa forma, o contato cada vez mais intenso com a sociedade envolvente finda por definir um contorno para os grupos domésticos ${ }^{11}$ marcado pela sazonalidade de parte de seus integrantes diante das tarefas agrícolas. O quadro que se forma é marcado pela presença de indivíduos que fazem uma interlocução mais próxima com a sociedade do entorno e em alguns momentos podem fazer parte de dois universos: rural e urbano.

11 Aqui se entende o grupo doméstico como "grupo constituído pelas pessoas que vivem, segundo a expressão dos antigos, da mesma panela, do mesmo pão e do mesmo vinho" (MENDRAS, 1978, p. 65). É o que Chayanov (1974) define como unidades de produção/consumo. 
Os pontos que podem diferenciar áreas rurais de urbanas são encontrados na região: maior dependência do meio ambiente, menor densidade populacional, maior homogeneidade nas características psicossociais, herança de papéis sociais e maior contato qualitativo entre os indivíduos ${ }^{12}$ são características presentes no cotidiano de Nova Redenção que se espraiam até o centro de Concórdia do Pará. Excetuando o núcleo da cidade, toda a área do município pode ser classificada como rural. De 1991 até 2000, a proporção entre população rural e urbana permaneceu dentro de um equilíbrio equitativo (Tabela 2 e Figura 3).

Tabela 2 - Município de Concórdia do Pará. População urbana e rural - 1991, 1996 e 2000.

\begin{tabular}{c|cccc}
\hline Ano & Urbana & Rural & Total \\
\hline 1991 & 7.694 & 7.553 & 15.247 \\
1996 & 9.359 & 9.110 & 18.469 \\
2000 & 10.848 & 10.108 & 20.956 \\
\hline
\end{tabular}

Fontes: IBGE. Censo demográfico, 1991/2000; IBGE. Contagem populacional, 1996.

Figura 3 - Município de Concórdia do Pará. População urbana e rural - 1991, 1996 e 2000.

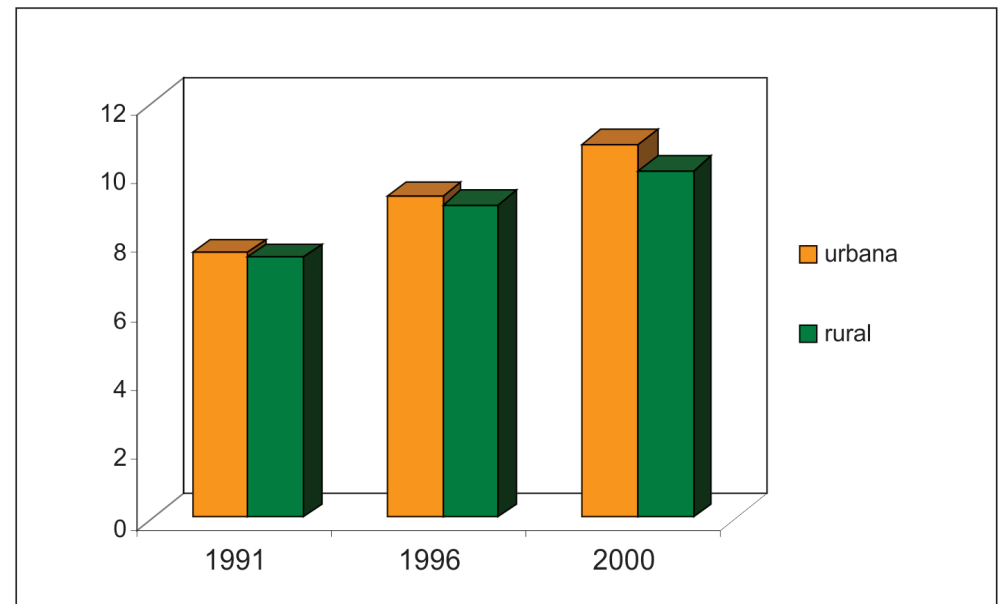

Fontes: IBGE. Censo demográfico, 1991/2000; IBGE. Contagem populacional, 1996.

12 Solari (1979), Abramovay (2003) e Wanderley (2001a) discutem características que marcam a vida rural. Considerando as inferências de Solari, a caracterização das sociedades rurais nos países em desenvolvimento se faz por meio de um contínuo, pois, dependendo dos tipos de exploração agrícola, os contornos dessas características podem ser alterados. Assim "é mais correto dizer que existe um contínuo, o que não impede que haja descontinuidades consideráveis entre os diversos grupos, quer dentro da própria sociedade rural, quer entre esta e a sociedade urbana, que se revelam sobre o fundo que o contínuo proporciona” (SOLARI, 1979, p. 14). 
É importante considerar que a metodologia atual utilizada para o cálculo sobre grau de urbanização no Brasil vem sofrendo questionamentos metodológicos. Veiga (2002) e Abramovay (2003) mostram como ainda na administração do Estado Novo buscou-se urbanizar o Brasil na tentativa de inseri-lo num contexto mundial industrializado. Apontam nesse movimento a inconsistência dos critérios classificadores que permanecem ainda hoje como instrumento de cálculo para o grau de urbanização do país ${ }^{13}$. Dadas essas considerações, é possível afirmar que a população rural de Concórdia do Pará é ainda maior do que aquela contabilizada oficialmente.

Nos últimos anos, o meio rural vem se valorizando não mais como um setor da economia responsável pelo fornecimento de matéria-prima ${ }^{14}$, mas a partir de valores relacionados a um modo de vida que o caracteriza: interação entre os indivíduos mais qualitativa que quantitativa, uma relação mais próxima com o meio ambiente e uma relação com a cidade marcada pela transferência de renda ${ }^{15}$. Assim, na perspectiva de ruralidade como um valor, Concórdia do Pará pode ser compreendida como zona rural ${ }^{16}$. Há uma trama social composta por conhecidos, parentes próximos e distantes que constrói um cenário marcado pelo contato permanente entre campo e cidade. Mesmo a relação com a capital do estado é intensa, sendo frequente o contato entre os moradores de Nova Redenção e seus familiares em Belém ${ }^{17}$.

A Tabela 3 indica as atividades que os moradores da localidade desenvolvem. Dividida em atividade principal e atividade secundária, elas apresentam a diversidade do cotidiano econômico em Nova Redenção.

13 Considerando a necessidade de revisão dos critérios e metodologias para a classificação de uma área urbana, é possível afirmar que "O Brasil é menos urbano do que se calcula" (VEIGA, 2002, p. 63).

14 A perspectiva apontada por estudos da Economia e mesmo das Ciências Sociais de que o processo de industrialização acabaria incorporando áreas de produção agrícola, não se confirmou. O final do século XX experimentou a revalorização do rural e da consolidação da ruralidade como valor em detrimento da ideia de agricultura como setor econômico (ABRAMOVAY, 2003, p. 11).

15 Abramovay resume as características que marcam a ruralidade como "[...] uma certa relação com a natureza (em que a biodiversidade e a paisagem natural aparecem como trunfos e não como obstáculos ao desenvolvimento), uma certa relação com as cidades (de onde vem parte crescente das rendas das populações rurais) e uma certa relação dos habitantes entre si (que pode ser definida pela economia da proximidade, por um conjunto de laços sociais que valorizam relações diretas de interconhecimento" (ABRAMOVAY, 2003, p. 13).

16 Analisando os dados estatísticos das atividades econômicas de pequenos municípios de Pernambuco, Wanderley (2001b) apresenta algumas conclusões preliminares que apontam a existência de uma trama social e espacial majoritariamente rural para tais municípios (WANDERLEY, 2001b, p. 13). Considerando o porte e a organização espacial entre a área rural e o centro de Concórdia do Pará, tais conclusões podem ser aplicadas também para essa cidade.

17 A construção da PA-140 possibilitou um contato mais frequente com Belém. Na expressão recorrente entre os moradores "hoje o camarada vai em Belém e volta duas vezes em um dia". 
Tabela 3 - Moradores de Nova Redenção por atividade principal e secundária.

\begin{tabular}{|c|c|c|c|}
\hline \multicolumn{2}{|c|}{ Atividade principal } & \multicolumn{2}{|c|}{ Atividade secundária } \\
\hline Aposentado, pensionista & 07 & - & - \\
\hline Casa/farinha & 01 & - & - \\
\hline Casa/roça & 02 & - & - \\
\hline Criança de 0-3 & 10 & - & - \\
\hline Cuida do local & 01 & - & - \\
\hline Cuidar da casa & 18 & $\begin{array}{l}\text { Diarista } \\
\text { Aposentada } \\
\text { Estuda } \\
\text { Faz farinha } \\
\text { Ajuda no gado } \\
\text { Estuda/ag.operacional }\end{array}$ & $\begin{array}{l}02 \\
01 \\
03 \\
03 \\
01 \\
01\end{array}$ \\
\hline Setor público & 03 & $\begin{array}{l}\text { Estuda } \\
\text { Roça }\end{array}$ & $\begin{array}{l}01 \\
02\end{array}$ \\
\hline Setor privado & 03 & Roça & 02 \\
\hline Roça & 54 & $\begin{array}{l}\text { Pensão } \\
\text { Estuda } \\
\text { Empreita } \\
\text { Diarista } \\
\text { Carpinteiro } \\
\text { Diarista/pimental } \\
\text { Pimental } \\
\text { Agente } \\
\text { Cria porco/pensão } \\
\text { Dona-de-casa } \\
\text { Serra madeira } \\
\text { Vende farinha }\end{array}$ & $\begin{array}{l}01 \\
02 \\
01 \\
08 \\
01 \\
03 \\
01 \\
01 \\
01 \\
01 \\
01 \\
01 \\
\end{array}$ \\
\hline Roça/casa & 04 & Estuda & 01 \\
\hline Estudante & 67 & $\begin{array}{l}\text { Casa de família } \\
\text { Roça } \\
\text { Casa } \\
\text { Faz goma } \\
\text { Casa/roça } \\
\text { Faz bico }\end{array}$ & $\begin{array}{l}03 \\
09 \\
07 \\
01 \\
02 \\
01\end{array}$ \\
\hline Gado e queijo & 05 & Roça & 04 \\
\hline Faz goma & 03 & \begin{tabular}{|l|} 
Casa \\
Estuda \\
\end{tabular} & $\begin{array}{l}01 \\
01 \\
\end{array}$ \\
\hline Faz bico & 01 & - & \\
\hline Falecido & 01 & - & \\
\hline Não informou & 03 & - & \\
\hline Total & 183 & & \\
\hline
\end{tabular}

Fonte: Pesquisa de campo (2004) 
Os indivíduos que estão classificados nas categorias atividade principal e atividade secundária aparecem de forma sobreposta. Assim, estudar e ajudar na roça são uma constante entre os integrantes do grupo. É importante notar, no entanto, que a somatória de estudantes corresponde à quase totalidade daqueles que estão entre 0 e 19 anos, sendo que as atividades na roça e domésticas (casa) correspondem às atividades secundárias preferenciais à atividade de estudar quando esta aparece como atividade principal. Essa proporção denota uma característica básica presente nas formas de exploração agrícola familiar: a utilização e formação das gerações mais jovens para o processo produtivo. A infância é repleta de obrigações pequenas vinculadas às tarefas simples do cotidiano. As atividades que demandam maior responsabilidade e destreza para sua realização devem ser destinadas a quem já as domina por meio de experiências acumuladas pelo trabalho diário. A Tabela 3 aparece com três atividades principais prioritárias: estudar, roçar e cuidar da casa. Essa divisão sintetiza a vida em Nova Redenção e corresponde a categorias nativas que definem as atividades mais importantes do cotidiano. Quanto maior a família e menor a terra a se herdar, mais cedo se faz presente a escolha entre sair ou permanecer. Na verdade, menos que uma escolha, essa é uma indicação, como visto, que os pais vão traçando no decorrer da vida dos filhos. Como mencionado, a permanência no grupo recai normalmente sobre a figura masculina. A inserção da mulher em trabalho doméstico na capital é mais segura e fácil.

Diferentemente de alguns anos atrás, hoje Nova Redenção tem mais contato com Belém, a capital do estado. Esse contato mais frequente se reflete nas formas de se portar de seus moradores. As mudanças no modo de se trajar e no comportamento saltam aos olhos dos que saíram do povoado há mais de cinco anos ${ }^{18}$. Exposição excessiva do corpo e formas de lazer centradas em jogos de bar compõem hoje o cotidiano do quadro. Todas as casas atualmente possuem televisão ${ }^{19}$ e a motocicleta tornou-se um meio de transporte popular para as famílias que possuem alguma renda fixa. Esse novo cenário permite maior contato com valores urbanos, reforçando o consumo de bens de mercado antes pouco expressivos na vida dos moradores. O número de casas que compõem a vila triplicou nos últimos cinco anos. Tal cenário não indica o crescimento da população, ou o aumento do número de grupos domésticos que compõem Nova Redenção, mas a concentração da população na área aonde chega energia elétrica, emergindo um panorama em que novas formas na reprodução social começam a

18 Essa é uma observação pessoal baseada em observação de campo, já que a área constituiu-se também no l'ocus de minha dissertação de mestrado.

19 Em trabalho de campo realizado entre 1997 e 1998 apenas uma casa possuía televisão. 
se delinear. No entanto, tais formas se modelam sobre um passado ao qual todos se remetem sempre que necessário e útil ${ }^{20}$.

\section{A HISTÓRIA DA LOCALIDADE}

Viver em Nova Redenção é ser colono e o relato da história de vida dos moradores é estabelecido a partir de uma perspectiva de família. O conceito de família aqui empregado corresponde ao de família extensa, considerando que a mesma "[...] resulta da extensão, no tempo e por intermédio de laços de casamento, das relações entre pais e filhos” (AUGÉ, 1978, p. 51). Caracterizandose como uma família de filiação indiferenciada, "[...] ela corresponde, idealmente, ao grupo formado por um casal e as demais famílias conjugais de todos os seus descendentes" (AUGÉ, 1978, p. 51). Devem-se considerar as famílias que compõem Nova Redenção a partir de um conceito êmico, já que o mesmo é utilizado como elemento de reconhecimento entre os seus integrantes.

A fala local sobre descendência e relação parental permeia a vida cotidiana. A maior parte dos moradores descende de um ancestral comum, daí ser frequente os moradores se considerarem parentes ${ }^{21}$. Quatro gerações se seguiram após a formação da localidade. Esta se deu entre as décadas de 1930 e 1940, quando os herdeiros do principal lote de terra que compõe Nova Redenção se estabeleceram na área, seguida da chegada da Igreja Assembleia de Deus à região e sua instalação no quadro em 1958. Dez famílias atualmente formam o lugar, mas há quatro mais antigas: Gomes da Conceição, Batista, Matos e Guimarães. Esta última foi originada por meio de um ancestral comum que liga todos os que lá vivem e dele advém a herança que garante o acesso à terra para a maior parte dos moradores. Nas fontes secundárias, pouco foi encontrado sobre a origem da família Guimarães ${ }^{22}$.

20 Sobre a origem de Nova Redenção, ver minha dissertação (Ravena-Canete, Voyner. Memória e herança da terra: a história de um grupo camponês do nordeste paraense - Nova Redenção/ Concórdia do Pará. Belém: DANF/CFCH/UFPA, 2000a). O estudo trata de uma família típica do nordeste paraense onde o acesso à terra está baseado na descendência de um ancestral comum e descreve uma estrutura prescritiva e performativa para a família Guimarães, principal família da localidade foco do estudo, que também é válida para Nova Redenção.

21 Para se considerar duas pessoas como parentes é necessário que elas descendam uma da outra, ou descendam ambas de um(a) antepassado(a) comum, elas seriam então chamadas de parentes cognáticos (RADCLIFFE-BROWN, 1995, p. 222-224). Considerando a compreensão do parentesco a partir da descendência, portanto, a maior parte dos integrantes de Nova Redenção pode ser vista como parente, pois descendem de um ancestral comum. No capítulo IV consta como se formou a localidade a partir do parentesco.

22 Dois códices especificamente apresentavam situações envolvendo indivíduos com sobrenome Guimarães. Eles correspondiam ao óbito de Valentino Guimarães de Matos e Jesuína Conceição 
As famílias Gomes da Conceição e Matos aparecem com maior frequência em documentos encontrados no arquivo público relativos ao então município de Bujaru durante as décadas de 1930, 1940 e 1950. Na lembrança dos moradores de Nova Redenção, essas famílias são originárias do "Baixo Bujaru”. Todavia, para a família Guimarães a ideia de um indivíduo que origina a história do lugar aparece de forma imperiosa ${ }^{23}$. Nova Redenção se formou a partir do casamento entre essas quatro famílias principais e eventualmente outras famílias que povoaram a localidade no decorrer dos últimos $50 \operatorname{anos}^{24}$. O ancestral mencionado para a família Guimarães conviveu com poucos dos que agora estão na localidade. A lembrança de outros parentes mais velhos marcando a trajetória do lugar também é mencionada como importante para a formação de Nova Redenção, mas nunca em uma perspectiva de fundação da localidade. Assim, a família Guimarães pode ser vista como uma família forte, pois pertencer a ela significa dispor de herança e, portanto, garantia de acesso à terra. A família Gomes da Conceição também apresenta um status semelhante, ainda que não tão destacado, mas efetivamente dela advém terras para seus descendentes que permitiram estabelecer trocas através de casamento com os Guimarães.

Das famílias que formam Nova Redenção, somente a Guimarães e a Gomes da Conceição ${ }^{25}$ possuem terras em forma de herança. As demais, ao chegarem à localidade, entre os anos de 1940 e 1950, apenas se colocaram ${ }^{26}$ em terras do Estado e, posteriormente, ao final os anos 1970, desfrutaram da herança decorrente dos casamentos entre Guimarães e Gomes da Conceição. A mobilidade das famílias no período entre os anos de 1930 e 1960 foi intensa. A ideia de disponibilidade irrestrita da terra permanece na segunda geração, ou seja, entre os indivíduos que nasceram entre as décadas de 1920 e 1940. Nesse período, a escolha do lugar para se fazer uma roça estava ligada ao acesso fácil e localização próxima para desenvolver as atividades da roça. Segundo a lembrança dos integrantes do grupo, a fartura

Guimarães. Esta última corresponde à esposa, portanto avó ou bisavó de todos os integrantes da família Guimarães que hoje ocupam Nova Redenção.

23 Para compreender a formação da família Guimarães em Nova Redenção, ver: Ravena-Cañete (2000b).

24 Durante os últimos 50 anos, os casamentos entre as famílias que compõem o lugar garantiram que a terra herdada pelos Guimarães permanecesse parcialmente com seu formato original, sendo ainda o parentesco usado pelo grupo como estratégia de acesso à terra (RAVENACAÑTE, 2000b).

25 A família Gomes da Conceição, detentora de terras deixadas como herança, aparecerá nessa condição por meio de Lucilo Gomes da Conceição. Na compreensão do grupo, esse parente inicia o processo de herança para os descendentes dessas famílias, portanto essa família é vista como Gomes da Conceição e não apenas Conceição.

26 Expressão usada entre os moradores diante da disponibilidade de terras quando chegaram a Nova Redenção. 
marcou esse período. De fato, nas décadas de 1940 a 1960 é possível detectar o aumento da produtividade da Zona Guajarina.

Ao final dos anos de 1960 o quadro de disponibilidade e acesso irrestrito à terra começa a se alterar em decorrência das políticas da União para a Amazônia ${ }^{27}$. É nesse novo quadro que a lembrança de um ancestral comum passa de elemento identitário $^{28}$ do grupo para mecanismo de acesso à terra. A partir da década de 1970, tal acesso começa a caracterizar-se pela herança. O principal terreno da área corresponde a terras herdadas pela família Guimarães. Esta, no decorrer de três décadas, casou-se preferencialmente com os Gomes da Conceição, como mencionado, mantendo o terreno o mais intacto possível e disponibilizando mais terrenos para a herança advindos da descendência Gomes da Conceição.

Enquanto em outras regiões de fronteira se forma um quadro de conflito agrário, em Nova Redenção o acesso à terra é baseado na descendência. Nesse novo quadro que emerge das limitações impostas pelo Estado para o acesso à terra, somado às políticas de desenvolvimento implementadas pela União, Nova Redenção experimentará as oscilações das demandas do mercado. De toda forma, o caráter de fornecedora de produtos agrícolas que delineia a história da localidade se mantém. A produção local passa pela banana, pimenta-do-reino, mas é a mandioca que se mantém e permanece configurando a região como fornecedora de farinha para os mercados locais e de Belém. Por esse motivo, é o calendário agrícola que orienta a vida social e produtiva em Nova Redenção.

${ }^{27}$ As transformações políticas e econômicas na Amazônia podem ser observadas em um quadro sintetizador por meio no trabalho de Petit (2003). O autor sugere "para fins analíticos, propor uma subdivisão da história econômica da Amazônia brasileira em três principais períodos: a) Ciclo da Borracha, 1850-1912; b) fase de declínio e posterior crescimento moderado da economia regional, 1912-1965; e c) época das grandes transformações sócio-econômicas da Amaz̧ônia, a partir da segunda metade da década de 1960 até os dias de hoje". "A última fase apresenta ainda a influência da crescente integração da economia regional ao mercado nacional e da intervenção da Administração Federal na Amazônia”. Mais adiante o autor prossegue suas definições para essa última fase: "o período das Grandes Transformações Socioeconômicas na Amazônia decorre da mudança nos objetivos e no grau de intervenção da Administração Federal na região, que não tem paralelo com nenhum outro momento anterior. Foi nesses meses que o governo modificou a lei de incentivos fiscais com o intuito de que fossem estendidos esses benefícios a projetos agropecuários na Amazônia Legal, e criou-se o Banco da Amazônia S. A. (BASA) e a Superintendência do Desenvolvimento Econômico da Amazônia (Sudam), subordinada ao Ministério do Interior. Em 1967, iniciou-se a implantação dos objetivos definidos no I Plano Quinquenal da Amazônia (1967-1971)" (PETIT, 2003, p. 49-50, p. 64-65). Essa última fase classificada por Petit ficou conhecida, dentro da academia pela expressão entrada dos grandes projetos ou grande capital na Amazônia.

28 Oliveira aponta questões que permitem compreender a descendência como fator de identidade: "Nessa linha de raciocínio a identidade social surge como atualização do processo de identificação e envolve a noção de grupo, particularmente a de grupo social. Porém, a identidade social não se descarta da identidade pessoal, pois esta também de algum modo é um reflexo daquela" (OLIVEIRA, 1976, p. 5). 


\section{O COTIDIANO AGRÍCOLA}

Os trabalhos para o plantio da roça iniciam-se nos meses de outubro a dezembro. Primeiro o terreno é brocado; depois, queimado. A broca é um processo composto do corte das árvores com o objetivo de deixar o terreno limpo e preparado para que o fogo possa consumir com a máxima eficiência as madeiras que ficaram no chão. Essas são as duas atividades iniciais do período de plantio e configuram-se como tarefas masculinas normalmente realizadas por dois ou três homens. Todavia, isso não quer dizer que uma mulher jamais poderá participar da limpeza de uma área. É possível encontrar uma família jovem, ainda no início do ciclo doméstico, ou seja, marido e esposa, brocando um terreno. Nesses casos, a mulher faz a figura de auxiliar, ajudando o marido na tarefa, mas sempre com um papel secundário.

Após essa etapa, deve acontecer a queimada. Dependendo do resultado da broca e da queimada, já se pode iniciar o plantio; caso ainda haja muitos restos de madeira, é necessário limpar o terreno novamente. Esse novo processo de limpeza é chamado coivara e somente acontece quando a queimada não foi intensa o suficiente para deixar o terreno nas condições necessárias para plantar (Figura 4).

Figura 4 - Área sendo preparada para o plantio: queimada.

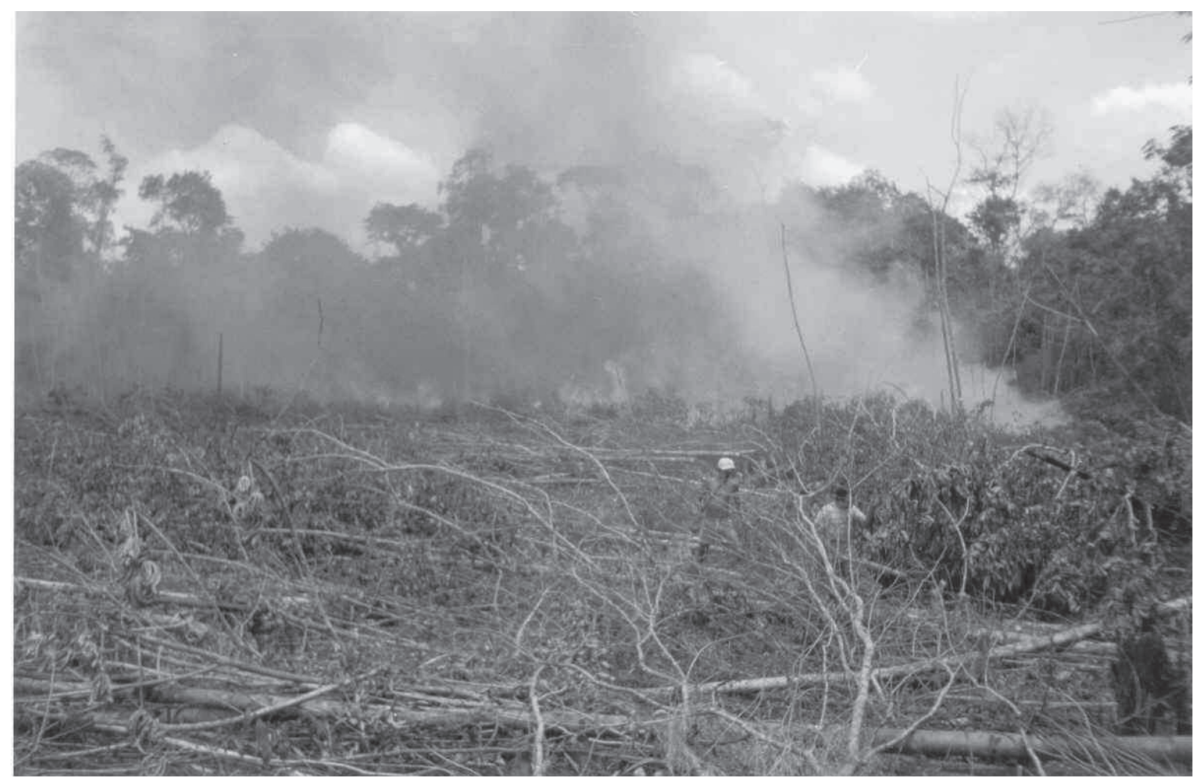

Fonte: Ravena-Cañete (2004). 
O calendário agrícola é norteado pela natureza e suas características de reversibilidade climática; neste caso, as duas estações do ano que caracterizam a área equatorial. Assim, são duas as roças fundamentais a serem realizadas em um ano agrícola: a roça de inverno e a roça de verão, ou seja, a plantação feita, respectivamente, no período de grande precipitação e aquela realizada no período caracterizado por pouca chuva.

O inverno acontece nos meses de dezembro a maio. Esse é o período no qual é feito o plantio mais importante do ano. Essa é a roça que ocupa maior área, pois de seu amadurecimento sairá a massa necessária para a confecção da farinha que sustentará a família no decorrer de todo o ano. Todavia, seus preparativos iniciam-se meses antes com o processo da broca. Essas duas atividades, broca e plantio, estão intrinsecamente ligadas e relacionadas com as estações chuvosa e seca.

Como visto, a técnica do corte e queima ainda configura-se como estratégia de plantio para a população de Nova Redenção e as escolhas das áreas para se fazer as roças obedecem a um critério organizador que está baseado nas estações do ano. A roça mais importante e, por consequência, mais extensa, deve ser feita em uma área que apresente maior garantia de êxito para a safra, ou seja, em terra forte, que significa solo rico em nutrientes. Essas áreas são aquelas onde se, encontram os capoeirões ${ }^{29}$. A broca, como já mencionado, é a técnica de limpeza da área para se fazer a roça. É brocando que se garante uma queimada exitosa, pois os galhos são cortados, secando por alguns dias sob o sol e, posteriormente, quando o fogo se instala, a combustão é perfeita, deixando os espaços livres entre as árvores maiores para o trânsito na área e o corte dos grandes troncos. Depois as árvores maiores, então já queimadas, são cortadas e o terreno está pronto para o plantio. Mas, para que uma queimada seja exitosa é necessário que a vegetação esteja suficientemente seca e, em se tratando de uma área de capoeirão, ou seja, com vegetação densa, é necessário mais de um mês sem chuvas para que isso aconteça. Por outro lado, as roças de verão são feitas em área de juquira ou capoeira fina. Para esse tipo de vegetação, uma semana sem chuva é suficiente para se queimar a área. Considerando que o solo onde se forma a juquira não é qualificado como terra forte, a roça de verão finda caracterizando-se como uma entressafra, enquanto a roça de inverno aparece como a plantação principal. A técnica do corte e queima

29 Os diversos tipos de vegetação encontrados na área possuem denominações específicas. Assim, uma vegetação que nunca foi tocada é chamada de mata, ao passo que, após um primeiro corte, a vegetação que cresce terá uma classificação a partir de sua densidade decorrente de seu tempo de desenvolvimento. Dessa forma, capoeirão ou capoeira grossa, refere-se a uma vegetação que cresceu por aproximadamente 30 anos após o corte. A capoeira média apresenta uma vegetação de aproximadamente 20 anos, enquanto que a capoeira fina tem em média 10 anos. Ainda existe a juquira, que denomina a vegetação rala que cresce nos primeiros anos após o uso da área para a roça. 
utilizada na área e a lógica para a escolha das roças, portanto, estão intimamente relacionadas às estações do ano.

O uso da tradicional técnica de plantio da mandioca vem acontecendo no decorrer de todas as gerações que formaram Nova Redenção, caracterizando assim o trabalho na roça como um saber específico sobre a natureza e a construção de estratégias no seu trato. Todavia, uma fala recorrente permeia atualmente o discurso dos moradores: "agora a gente não sabe mais quando plantá. Quando parece que vai pará de chover, a gente menos espera e vem aquela chuvona e a gente nem pode brocá" (J. G., 65 anos).

De fato, as estações do ano parecem não obedecer mais a uma sequência lógica antes conhecida e dominada pela população local. A previsibilidade das estações, característica fundamental para o planejamento agrícola, parece-lhes já não ser tão segura. Todos os grupos domésticos entrevistados alegaram dificuldades relacionadas ao uso da técnica de corte e queima em decorrência de alterações frequentes nas estações de chuva ou seca. É esperado que eventualmente um verão chegue mais cedo, ou um período chuvoso se estenda mais, todavia aqui se fala em grande imprevisibilidade de estações. É interessante notar ainda a compreensão da população para os motivos que poderiam estar originando essa mudança: o avanço das fazendas, logo pastagem para gado, em detrimento da mata e mesmo dos capoeirões. Uma expressão local pode ser esclarecedora: "mata chama chuva".

As conversas sobre as fazendas que se instalam na região percorrem a temática cotidiana. Como mencionou um morador: "Se procurar por toda essa estrada até Bujaru, não tem um só colono, é só fazenda”. Agregada a essa percepção, está o argumento relacionado à diminuição do volume de água nos igarapés. Para essa compreensão, pode-se evocar a seguinte fala relacionada à memória sobre os corpos d'água: "antes a gente transportava tudo pelo igarapé. Era uma semana de viagem até Belém. Primeiro no igarapé, de casco, depois em barco de motor até Belém” (I. B. G., 42 anos). Essas falas sugerem que a percepção sobre o meio ambiente vem sofrendo alterações e que os critérios que vêm orientando as práticas de interação com a natureza, inseridos em um saber local, estão sofrendo testes sobre sua eficiência. O saber que orientou as várias gerações que formaram Nova Redenção e que garantiram a reprodução física e social do grupo começa a receber os questionamentos relativos às alterações ambientais em decorrência das mudanças climáticas vividas no decorrer das duas últimas décadas na Amazônia ${ }^{30}$.

Assim, o ciclo agrícola em Nova Redenção é marcado por várias etapas diretamente relacionadas com a disponibilidade dos recursos naturais para o grupo. O ciclo agrícola é planejado a partir dos trabalhos do plantio da mandioca e da

30 Sobre mudanças do clima na Amazônia, ver Monzoni (2000) e Schlesinger (1991). 
necessidade dessa cultura para a produção da farinha. Esta pode aparecer apenas como produto destinado ao consumo ou assumir grande parte das atividades econômicas do grupo.

A forma mais comum para se designar uma roça de mandioca é chamá-la de roça de farinha, tal a importância que esse alimento tem na vida dos integrantes do grupo. Normalmente as famílias cultivam farinha em mais de $80 \%$ do terreno destinado ao plantio. De modo geral, são mantidas várias roças, entre maduras e verdes, de forma a garantir que permanentemente haja mandioca para a produção da farinha. Houve o tempo em que se plantava também juta e arroz, por exemplo, para comercialização. Mas as dificuldades para o escoamento no mercado findaram por restringir a produção desse tipo de cultura apenas para o consumo. No caso da juta, em especial, essa dificuldade está relacionada ao surgimento dos sacos de polietileno, que substituíram os de origem vegetal. Mas, atravessadores e o transporte muito caro são os fatores que mais comumente inviabilizam a comercialização. Apesar de a área ser grande produtora de pimenta, poucas são as famílias que a cultivam, pois, como essa cultura demanda muitos insumos agrícolas, torna-se inviável como alternativa econômica para os grupos domésticos. Algumas famílias plantam pimenta em no máximo uma ou duas tarefas ${ }^{31}$ de terra, pois não se pode colocar em risco as atividades econômicas que de fato garantem a subsistência do grupo ${ }^{32}$.

As demais culturas plantadas destinam-se, de forma geral, ao consumo e, com exceção da pimenta, são feitas junto com a roça de farinha. Entre as fileiras da mandioca, plantam-se arroz, milho, feijão e verdura. Esta última é a generalização de várias espécies como cariru, feijão de corda, maxixe, cheiro-verde e pimenta, por exemplo. Mas essas verduras também podem ser plantadas em um jirau ${ }^{33}$ próximo à casa da família, já que normalmente é a mulher que cuida ou se preocupa em plantá-

31 Tarefa é a especificação local feita para a área a ser plantada, ela funciona como uma medida. Cada tarefa mede $25 \times 50$ braças, sendo que cada braça possui aproximadamente um metro.

32 Woorttmann, E. e Woorttmann, K. (1997) mostram como as alternativas para a produção agrícola são tratadas, "O sistema de cultivo constitui um todo preconcebido, no qual vários fatores são levados em conta: solo, clima, consumo familiar, relações de mercado, disponibilidade de força de trabalho etc. Um todo complexo que envolve cálculos sutis que, frequentemente, passam despercebidos ao pesquisador" (WOORTTMANN, E.; WOORTTMANN, K., 1997, p. 87).

33 Jirau: [do tupi yi 'rab.] S.m. Estrado de varas sobre forquilhas cravadas no chão, usado para guardar panelas, pratos, legumes etc. (Novo Dicionário Aurélio da Língua Portuguesa). É uma pequena construção de madeira entre $0,80 \mathrm{~m}$ a $1,28 \mathrm{~m}$ acima do chão e feita próxima à casa. $\mathrm{O}$ jirau serve para lavar a louça e demais utensílios de cozinha, realizar as tarefas necessárias para o preparo das refeições, enfim, é no jirau que se realiza parte das atividades femininas domésticas. Em uma parte dele podem ser plantadas as verduras que a família irá consumir. Considerando que o plantio e demais cuidados com as verduras são tarefas femininas, não é de se estranhar que no jirau também se realize várias outras tarefas domésticas. 
las, pois são o complemento ou o incremento nas refeições. Os meninos seguem o pai no decorrer da execução dos trabalhos, enquanto as meninas acompanham a mãe nas tarefas domésticas e demais obrigações femininas. Dessa forma, quando estiverem em idade para iniciar um novo grupo doméstico, os filhos estarão prontos para reproduzir o conjunto de conhecimentos no qual foram formados.

A farinha aparece em Nova Redenção como outra etapa da produção agrícola. Fazer farinha é realmente uma atividade cansativa. No entanto, no decorrer da realização dessa atividade, os laços de solidariedade e de identidade social se fortalecem. O processo da produção da farinha é longo, o que significa dizer que se passa o dia todo no retiro quando esta é produzida. São necessários muitos braços dedicados a essa tarefa, pois, segundo o jargão local, "quando começa não pode parar". O processo de produção da farinha está dividido basicamente em 4 etapas: cevar, prensar, coar, escaldar e torrar. Estes dois últimos movimentos referemse a uma mesma ação.

Diferentemente da confecção anterior, antes de alguns avanços tecnológicos, quando ao cevar a mandioca para a obtenção da massa era necessário toda a família raspando (descascar) a raiz, hoje essa etapa é realizada por meio de um motor movido a gasolina, que economiza muitas horas de trabalho e esforço físico do grupo que trabalha. De modo geral, quem ceva a massa é um homem. Depois de cevar, é necessário retirar o tucupi por meio da prensa. Após essas duas etapas, é preciso coar a massa para que ela seja escaldada e depois torrada no forno construído com chapa de cobre, chegando-se então ao produto final.

Existe mais de um tipo de farinha resultante da massa da mandioca: farinha puba, farinha d'água, farinha seca. Os processos de produção desses três tipos de farinha são semelhantes, mas as variações existentes são suficientes para produzir um resultado diferente no produto final. A mais consumida e vendida em Nova Redenção é a farinha d'água. Essa é uma mistura da farinha puba e da farinha seca, ainda na forma de massa.

Normalmente ocupa-se um dia inteiro fazendo farinha, sobretudo quando ela está destinada para a venda. Nesses casos o retiro escolhido deve ter mais de um forno, pois as etapas de produção estarão acontecendo todas ao mesmo tempo. Nessas ocasiões todos os membros da família participam da atividade, inclusive as crianças realizando tarefas de menor responsabilidade. Os grupos domésticos são parceiros constantes na produção da farinha, cuja venda do produto final acontece de forma alternada entre estes. Assim, dois grupos domésticos podem trabalhar juntos para produzir farinha para a venda. Em uma semana trabalhase com a mandioca de um dos grupos, sendo o ganho obtido com a venda da farinha destinada a ele. $\mathrm{Na}$ outra semana todos trabalham para fazer farinha com 
a mandioca do outro grupo parceiro e assim completar a reciprocidade ${ }^{34}$ no processo produtivo. Essa reciprocidade normalmente se dá a partir dos laços de parentesco. Uma mulher pode deslocar todo seu grupo doméstico para ajudar a família de sua irmã a produzir farinha, por exemplo, com a certeza de que, quando necessário, essa mesma ação será realizada para seu interesse. Essa reciprocidade acontece não necessariamente com atividades iguais, mas de forma equivalente. Quem ajuda na produção da farinha sabe que pode demandar mais braços para brocar seu terreno dentro do grupo ao qual ajudou, por exemplo.

A produção da farinha configura-se como atividade que compõe grande parte do cotidiano dos moradores da área, mesmo no período da cata da pimenta, quando os moradores diminuem a frequência e intensidade das demais atividades costumeiras. A farinha é o alimento básico na Amazônia (ALBUQUERQUE, 1969) e falar de farinha significa descrever o cotidiano dos moradores de Nova Redenção.

\title{
5 NOVA REDENÇÃO: UM CAMPESINATO AMAZÔNICO
}

\begin{abstract}
"Quando estou falando de mundo rural, refiro-me a um universo socialmente integrado ao conjunto da sociedade brasileira e ao contexto atual das relações internacionais [...] Porém, considero que este mundo rural mantém particularidades históricas, sociais, culturais e ecológicas que o recortam como uma realidade própria, da qual fazem parte, inclusive, as próprias formas de inserção na sociedade que o engloba" (Maria de Nazareth Baudel Wanderley).
\end{abstract}

Ao longo do tempo, Nova Redenção permanece com as mesmas características que lhe deram origem: ser formada por um grupo de produtores familiares para o qual as relações de parentesco delineiam e estruturam "uma vontade de conservação e de crescimento do patrimônio familiar" (WANDERLEY, 1996, p. 6). Tal afirmação demanda algumas considerações teóricas que permitam classificar o grupo dentro do escopo atual da discussão sobre campesinato, agricultura familiar e pequeno produtor rural.

34 Entende-se a reciprocidade como a obrigação de dar, receber e retribuir (MAUSS, 1974). Analisando Mauss, Godelier afirma que: "Dar parece instituir simultaneamente uma relação dupla entre aquele que dá e aquele que recebe. Uma relação de solidariedade, pois quem dá partilha o que tem, quiçá o que é, com aquele a quem dá, e uma relação de superioridade, pois aquele que recebe o dom e o aceita fica em dívida para com aquele que deu. Através dessa dívida, ele fica obrigado e, portanto, encontra-se até certo ponto sob sua dependência, ao menos até o momento em que conseguir 'restituir' o que lhe foi dado" (GODELIER, 2001, p. 23). Essa obrigação de dar, receber e retribuir pode ser encontrada entre os moradores de Nova Redenção e sua discussão pode ser encontrada em Ravena-Cañete (2005), mais especificamente no capítulo V. 
Nas diversas definições e debates sobre a exploração camponesa dentro das Ciências Sociais, a força de trabalho, em conjunto com a disponibilidade de uso da terra, aparecem sempre como fatores fundamentais para caracterizar a economia camponesa e a reprodução do grupo doméstico. Os matizes que separam a riqueza da discussão de autores valem ser observados para se perceber as possibilidades de sua aplicabilidade na compreensão de Nova Redenção. Necessário se faz recorrer a tal discussão.

As linhas de pensamento que estudam o campesinato apresentam análises sobre formas camponesas específicas. O processo histórico representa fator importante nessa configuração. Nesse sentido, por exemplo, Ellen Woorttmann afirma que "[...] O camponês latino-americano é pensado a partir do modelo de dominação colonial hispânico ou luso, tal como o camponês europeu era pensado a partir da totalidade representada pelo feudalismo" (WOORTTMANN, E., 1995, p. 42). A visão econômica clássica argumenta que a economia camponesa daria lugar às relações econômicas capitalistas da sociedade envolvente, ou seja, o camponês sofreria um processo de proletarização. A história não confirmou essa inferência, mas mostrou que o Estado foi o responsável pela inserção do camponês no mercado quando este não conseguia fazê-lo por seus próprios meios.

São as análises de Chayanov (1974) que possibilitam uma nova visão sobre o futuro do campesinato na sociedade capitalista. Ao conferir grande importância à mão de obra familiar para a reprodução do grupo camponês, o autor demonstra que a composição e o tamanho da família determinam o montante da força de trabalho, logo, ela seria um dos fatores mais importantes para a organização da unidade econômica camponesa. A força de trabalho da unidade doméstica depende dos membros capacitados da família, sendo ela o fator mais influente na determinação do volume de atividade do grupo ${ }^{35}$. Diante de tal perspectiva o autor é enfático ao apontar o estudo do trabalho da família e o ciclo do grupo doméstico como fundamentais para se compreender o campesinato.

Segundo Chayanov, na visão camponesa os integrantes de uma família são todos aqueles que "comem sempre na mesma mesa e da mesma panela" (CHAYNOV, 1974, p. 48). Nessa perspectiva, a definição de uma família não obedece, portanto, a leis estabelecidas, mas sim a escolhas sociais realizadas pelo grupo. Ainda que possuindo membros de diferentes gerações, a família possui um

35 Descrevendo a importância da família para a reprodução camponesa, Chaynov afirma que "la fuerza de trabajo familiar define ante todo los límites máximo y mínimo del volumen de su actividad económica. La fuerza de trabajo de la explotación doméstica está totalmente determinada por la disponibilidad de miembros capacitados en la familia. Por eso es que el límite del monto de trabajo que puede proporcionar esta fuerza de trabajo utilizada con la máxima intensidad" (CHAYANOV, 1974, p. 47). 
ciclo que perfaz aproximadamente 25 anos. Isso quer dizer que nos seus primeiros anos de existência há um aumento do número de seus integrantes por meio do nascimento dos filhos, levando a uma maior proporção de consumidores em relação aos produtores. Essa realidade é modificada quando o filho mais velho completa 15 anos. A partir daí ele já pode ajudar os pais nas atividades produtivas dentro do grupo, alterando, por fim, a proporção entre consumidor/trabalhador. Todavia, essa relação consumidor/trabalhador pode variar conforme a história de cada família.

Mendras (1978) retoma o pensamento explicativo central de Chayanov - a relação consumidor/trabalhador - para definir as especificidades do campesinato europeu. Apesar de estabelecer fortes laços com a sociedade capitalista envolvente, ainda assim o camponês continua vivendo por meio de uma lógica própria (MENDRAS, 1978, p. 46). Por meio de uma análise contábil, o autor mostra a relação posse da terra/assalariamento/lucro, indicando algumas das situações do campesinato europeu em que a lógica do capitalismo não consegue explicar a permanência do campesinato enquanto modo de produção dentro de uma sociedade capitalista.

É nesse sentido que, segundo Mendras, na lógica camponesa são a terra e o trabalho familiar os fatores nos quais baseiam-se os camponeses para regerem suas vidas, dentro de uma economia envolvente. Estes sim são fatores que devem ser utilizados da melhor forma possível. Isso inclui dizer que, se for necessário, um grupo doméstico diminui seu consumo para poder lançar uma maior quantidade de produtos no mercado, se este assim exigir ${ }^{36}$. Portanto, produção e consumo mostram-se como condicionantes para a relação com o mercado.

Explorando essa definição, Shanin (1976) estabelece de forma mais específica o que se quer dizer quando se fala em campesinato, e, para tanto, aponta quatro facetas essenciais que caracterizam esses grupos. A primeira delas seria o que já foi explicitado por Chayanov: a exploração agrícola familiar constituindo-se como a unidade básica e multifuncional dentro da organização social camponesa; a segunda está relacionada ao trabalho na terra e à atividade pecuária como principais meios de vida; em terceiro lugar estaria a tradição específica ao modo de vida camponês; a quarta e última característica essencial ao campesinato seria a subordinação à direção de agentes externos. No entanto, essas características podem ser encontradas em um amplo espectro de grupos sociais. Dessa forma,

36 Para essa questão, o autor aponta: "Sendo o consumo ao mesmo tempo a parte mais importante e a mais elástica, disso se segue que a redução ou o aumento desta parte é decisiva para o equilíbrio da economia doméstica: se as bocas não são mais numerosas que os braços, a produção pode diminuir ou a poupança aumentar. Ao se decidir pela privação, decide-se poupar, portanto, enriquecer" (MENDRAS, 1978, p. 48). 
segundo o próprio autor, para definir campesinato, deve-se considerar que o mesmo necessita ser entendido como um processo ${ }^{37}$. Para Shanin, o campesinato constitui-se e é constituído simultaneamente. Sua caracterização seria dada pela relação que estabelece com o entorno social.

Falar sobre campesinato significa, dessa forma, falar de grupos organizados que possuem semelhanças em suas formas de reprodução e que são encontrados em todas as partes do mundo (REDFIELD, 1960). Dessa forma, a configuração de campesinato enquanto categoria analítica envolve uma comparação entre grupos camponeses, ainda que tais grupos estejam inseridos em contextos históricos diversos. Essa comparação possibilita encontrar um perfil aproximado para o que seria campesinato. A exploração agrícola familiar dentro dos moldes colocados por Chayanov, no entanto, continua sendo o fator-chave que caracteriza o modelo camponês.

Nas definições de Shanin, no entanto, a unidade familiar toma proporções mais amplas ${ }^{38}$. A socialização do trabalho configura-se como elemento que reforça os laços familiares. A agricultura baseada no modelo camponês, portanto, está fortemente atrelada à família como unidade de reprodução do conhecimento e das técnicas agrícolas.

Ainda dentro da perspectiva da família como unidade fundamental do grupo doméstico, devem-se considerar as inferências de Fortes (1982) sobre essa questão. Apontando as diferentes fases que compõem o ciclo de vida do grupo doméstico - formação e crescimento, dispersão e dissolução -, Fortes mostra a estreita relação entre a unidade de produção e a família. A família aparece como fator elementar da unidade de produção, podendo em alguns casos configurar-se como o próprio grupo doméstico. De qualquer forma, os laços que unem o grupo doméstico nem sempre são os mesmos que unem a família. Todavia, a questão que permanece diante desta discussão refere-se à lógica que orienta esses grupos produtores. Esta se constrói a partir de critérios diferentes daqueles que orientam

37 Explicitando a lógica processual apontada por Shanin, é importante salientar que o campesinato deve ser visto: “[...] como una entidad histórica dentro del marco más amplio de la sociedad aunque com estructura, consistencia y momentos propios: emergiendo, representando em cierto estadio el modo predominante de organización social, desintegrándose y volviendo a emerger en algunos momentos" (SHANIN, 1976, p. 8).

38 A compreensão das habilidades individuais e de grupo para a reprodução social camponesa deve ser vista a partir de que: "La ocupación productiva de un campesino consiste en un amplio espectro de tareas interrelacionadas, a un nivel de especialización relativamente bajo. Las habilidades se definen en términos de experiencia transferida directamente o se formalizan en una tradición oral de numerosos proverbios y relatos. La preparación de la ocupación de un campesino se cumple, principalmente, dentro de la familia: el joven prende su trabajo siguiendo a su padre y ayudándolo. Este procedimiento de la socialización refuerza los lazos familiares y realza el carácter tradicional de la agricultura campesina” (SHANIN, 1976, p. 19). 
a prática produtiva do capitalismo industrial. É nesse sentido que as formas de reprodução do grupo doméstico, ainda que alteradas pelas diferentes formas de acesso ao uso da terra - arrendamento, posse, uso, propriedade - persistem utilizando como critério orientador uma lógica não afeita às práticas do sistema capitalista.

A aplicabilidade de tais referências teóricas pode ser observada em trabalhos como "A morada da vida", de Beatriz Alásia Herédia (HEREDIA, 1979), ou “Terra de trabalho", de Afrânio Garcia Jr. (GARCIA, 1983). Estas são etnografias que revelam uma face importante do campesinato nordestino brasileiro e apontam a relação com o mercado como fator essencial para a condição de camponês. A mesma compreensão pode ser vista também para os trabalhos sobre o campesinato na Amazônia. Ianni (1978), Silva (1982), Guerra (2001) são alguns exemplos de trabalhos que trataram da questão do camponês, revelando a relação com o mercado como característica fundamental.

As definições estabelecidas pela discussão sobre campesinato podem ser encontradas no grupo de produtores rurais de Nova Redenção, pois estes se caracterizam pela composição de grupos domésticos produtores/consumidores, considerando os seguintes fatores: a) todas as famílias possuem roças de mandioca para a produção de farinha, que pode ser vendida, mas obrigatoriamente também consumida, sendo que a essas roças somam-se as de arroz, de milho e plantações menores de verduras, feitas entre essas plantações; b) as famílias normalmente possuem algum tipo de criação de animais, como galinhas ou porcos, que são usados para o próprio consumo, além, em alguns casos, do animal usado para ajudar no trabalho da roça; c) em decorrência dos itens anteriores, a terra é o meio de vida fundamental para a reprodução do grupo; d) apesar do contato com o mercado, o grupo permanece com uma lógica específica para a sua reprodução; e) a aprendizagem de como realizar as tarefas que garantem a manutenção do grupo acontece dentro de um conjunto de conhecimentos que é repassado por meio das relações pessoais, mais especificamente dentro da família; f) a perspectiva de que os esforços e investimentos feitos pela geração atual na unidade de produção serão transmitidos às gerações seguintes.

Definindo a exploração familiar como conceito de análise, Lamarche (1993) aponta ainda a possibilidade de compreensão do campesinato a partir de uma ótica comparativa e de complementaridade entre Mendras e Chaynov. Tal comparação apresenta pontos fundamentais em comum para a definição de campesinato encontradas nos dois autores: inter-relação da organização da produção com as necessidades de consumo; o trabalho familiar avaliado fora da lógica de lucro, já que tal trabalho não é quantificável para o grupo; a produção visa valores de uso 
e não de troca. Esses princípios apontados por Chayanov são, para Lamache, complementados pelas cinco características apresentadas por H. Mendras para a exploração camponesa, a saber: "a autonomia relativa em relação à sociedade como um todo; a importância estrutural do grupo doméstico; um sistema econômico de autarquia relativa; uma sociedade de inter-relacionamentos; a função decisiva das personalidades de prestígio que estabelecem uma ligação entre a sociedade local e a sociedade em geral" (LAMARCHE, 1993, p. 16).

Seguindo a argumentação comparativa e de complementaridade proposta por Lamarche, a existência de um modelo camponês pode ser utilizada para a compreensão de diversas realidades dentro da América Latina, assim como outras regiões em desenvolvimento no mundo. A questão que se coloca aponta para a permanência desse modelo de exploração familiar em países com algumas características específicas, como o Brasil, ainda que tal modelo tenha sido apontado por Mendras com seu destino selado pelo desaparecimento. Nesse sentido, Wanderley (1996) descreve a formação do campesinato a partir de quatro peculiaridades: a) "sistema de policultura-pecuária"39; b) o "horizonte das gerações" ${ }^{40}$; ) "as sociedades de interconhecimento e a autonomia das sociedades rurais" ${ }^{41}$; d) os conceitos para agricultura camponesa, agricultura de subsistência e pequena agricultura.

Com relação a esse último item, Wanderley ressalta que produção de subsistência, apesar de compor o cenário camponês, não o reduz a ela já que a necessidade de "conservação" e "crescimento do patrimônio familiar" regem as escolhas do grupo, guardando sua característica camponesa. Por outro lado a "pluriatividade e o trabalho externo" não distorcem o modelo de produção camponês, pois se transformam, na realidade, em uma estratégia a mais para superar os momentos de infortúnio do grupo. Ao mesmo tempo, como aponta a

39 Wanderley cita Mendras em uma definição sintetizadora de policultura-pecuária: “toda a arte do bom camponês consistia em jogar sobre um registro de culturas e criações o mais amplo possível e a integrá-los em um sistema que utilizasse ao máximo os subprodutos de cada produção para as outras e que pela diversidade de produtos fornecesse uma segurança contra as intempéries e as desigualdades das colheitas" (MENDRAS apud WANDERLEY, 1996, p. 3).

40 Nesse sentido, Wanderley define a geração em uma perspectiva em que "Para enfrentar o presente e preparar o futuro, o agricultor camponês recorre ao passado, que lhe permite construir um saber tradicional, transmissível aos filhos e justificar as decisões referentes à alocação dos recursos, especialmente do trabalho familiar, bem como a maneira como deverá diferir no tempo o consumo da família" (WANDERLEY, 1996, p. 4, 5).

41 A autora mostra a autonomia camponesa na relação com a sociedade envolvente. Salienta a presença de uma sociabilidade que permite que todos tenham conhecimento sobre a vida dos integrantes do grupo. Ressalta, ainda, o contato com a sociedade maior estabelecido por meio da troca dos produtos originados na produção camponesa, inserindo, no interior do grupo, elementos exógenos a ele. 
autora, a agricultura camponesa não deve ser pensada a partir de dimensões, assim, "a agricultura camponesa é, em geral, pequena, dispõe de poucos recursos e tem restrições para potencializar suas forças produtivas; porém, ela não é camponesa por ser pequena, isto é, não é a sua dimensão que determina sua natureza e sim suas relações internas e externas" (WANDERLEY, 1996, p. 6).

É nesse sentido que se torna possível considerar os moradores de Nova Redenção como camponeses: apesar da relação intensa com a sociedade do entorno e da inserção de novos elementos no cotidiano do grupo resultantes dessa relação, as estratégias usadas por seus integrantes ainda consideram, dentro de uma preocupação com as gerações futuras, a manutenção da terra como prioritária. A eventual inserção no mercado de trabalho como alternativa para momentos de dificuldade é recorrente, ainda que tal característica não seja necessariamente uma situação de pluriatividade. A produção baseada na exploração familiar dentro dos moldes camponeses ainda é a regra em Nova Redenção. Das 37 famílias que compõem a localidade, 30 constituem-se em grupos domésticos marcados pela relação produtor/consumidor apresentando diversificada relação com o mercado. Da venda da força de trabalho por meio da ocupação como diarista nos pimentais da região, ou mesmo na capina das roças de outros moradores de Nova Redenção, as atividades que envolvem o ciclo da produção agrícola de seus próprios roçados ainda se configuram como prioritárias.

Somadas a essas definições, casamento e parentesco também aparecem em Nova Redenção como mecanismos orientadores da lógica e ação dos moradores ${ }^{42}$. As relações de descendência legitimam o acesso à terra, como já mencionado. Existem basicamente quatro famílias que lá vivem desde a primeira metade do século. O princípio cognático rege as relações de herança, pois homens e mulheres são igualmente herdeiros. Partindo desse princípio, os casamentos se dão pelas possibilidades da permanência da terra entre parentes, assim como da disponibilidade apresentada na herança. No grupo, a descendência é perpetuada por meio da memória ${ }^{43}$, possibilitando o acesso à terra e a reprodução dos

42 Wolf (1970), Mendras (1978) e Redfield (1960), somada a vasta referência antropológica, apresentam o parentesco como ponto fundamental na compreensão desses grupos.

43 Para se entender o que se tem por memória e como aqui é aplicado, vale ressaltar que "[...] A memória é, em parte, herdada, não se refere apenas à vida física da pessoa. A memória também sofre flutuações que são função do momento em que ela é articulada, em que está sendo expressa. As preocupações do momento constituem um elemento de estruturação da memória. Isso é verdade também em relação à memória coletiva, ainda que essa seja bem mais organizada. Todos sabem que até as datas oficiais são fortemente estruturadas do ponto de vista político" [...] "Esse último elemento da memória - a sua organização em função das preocupações pessoais e políticas do momento - mostra que a memória é um fenômeno construído" (POLLAK, 1990, p. 204). 
saberes relacionados ao seu uso. Todos os moradores conhecem a história de Nova Redenção por meio da lembrança de um antepassado comum que deixou a terra como herança para os descendentes. Dessa forma, a descendência é o que legitima o acesso à terra, mas é acionada porque está perpetuada através da memória. É importante salientar que a memória acionada é uma memória coletiva, na qual todos se reconhecem. Em Nova Redenção, todos são parentes, desde que reconhecido entre os moradores como tal, permitindo que o uso e posse da terra sejam legitimados porque todos compartilham de uma mesma lembrança. Entre grupos camponeses, o conhecimento da roça e as técnicas utilizadas referem-se a um conjunto de conhecimentos construído no decorrer de várias gerações (WOORTTMANN, E.; WOORTTMANN, K., 1997). As relações com a natureza e seu manejo não fogem a essa regra. A memória, portanto, configura-se como instrumento fundamental na manutenção desse saber.

Falar sobre o acesso à terra em Nova Redenção corresponde a pensar sobre parentesco e memória. O parentesco funciona como um orientador da vida dos moradores em diferentes instâncias. Assim, a descendência pode ser o legitimador do acesso à terra, ou pode ser também o reconhecimento de uma relação de parentesco, o que garante a obtenção dos elementos econômicos básicos de sobrevivência. A identidade, por sua vez, é garantida por meio de relações de parentesco, pois estas apontam a descendência e, portanto, o pertencimento do indivíduo a um grupo. O parentesco caracteriza-se, ainda, como o instrumento legitimador de uma memória que reproduz o saber, sendo que este pode ser visto como o elemento que origina as práticas de uso dos recursos naturais e trato da natureza. Dentro dessa perspectiva é possível perceber, portanto, como a família tem uma força importante, dentro de Nova Redenção, configurando-se como opção principal para se efetivar estratégias de reprodução social. Vastos e fortes são os elos e as situações onde essa relação de parentesco é utilizada.

A questão que permanece no decorrer dessa descrição e delimitação do objeto deste estudo relaciona-se às escolhas que os moradores de Nova Redenção estabelecem para garantir o processo produtivo e sua relação com o mercado. As pressões que este faz sobre os integrantes da localidade não impedem que uma lógica específica permaneça como orientadora de suas práticas. Nessa lógica, "ganhar dinheiro", como diriam os moradores de Nova Redenção, ainda é o que menos importa. 


\section{REFERÊNCIAS}

ABRAMOVAY, R. Paradigmas do capitalismo agrário em questão. Campinas: Hucitec-Anpocs, 1992.

O futuro das regiões rurais. Porto Alegre: Editora UFRGS, 2003.

ALBUQUERQUE, M. A mandioca na Amazônia. Belém: Sudam, 1969.

AUGÉ, M. Os domínios do parentesco. Lisboa: Edições Setenta, 1978. (Coleção Perspectivas do Homem)

CASTRO, E. M. R. de. Relatório de Pesquisa Bujaru - Projeto Raízes. Belém: Goveno do Estado do Pará, 2003.

CHAYANOV, A. La organización de la unidad económica campesina. Buenos Aires: Ediciones Nueva Visión, 1974.

FORTES, M. O ciclo de desenvolvimento do grupo doméstico. Introdução. In: The Developmental Cycle in Domestic Groups. Cambridge: Jack Goody, 1982. (Papers in Social Anthopology, 1).

GARCIA, A. R. Terra de trabalho. Rio de Janeiro: Paz e Terra, 1983.

GODELIER, M. O enigma do dom. Rio de Janeiro: Civilização Brasileira, 2001. GUERRA, G. A. D. O posseiro da fronteira: campesinato e sindicalismo no Sudeste Paraense. Belém: NAEA/UFPA, 2001.

HÉBETTE, J. Estudos e problemas amazônicos: história social e econômica e temas especiais. Belém: Cejup, 1992.

HÉBETTTE, J.; ACEVEDO, R. Colonização para quem? Belém: NAEA/UFPA, 1979a.

Colonização espontânea, política agrária e grupos sociais. In: COSTA, J. M. da (Ed.). Amazônia: desenvolvimento e ocupação. Rio de Janeiro: IPEA/ INPES, 1979b.

HEREDIA, B. M. A. A morada da vida: trabalho familiar de pequenos produtores do Nordeste do Brasil. Rio de Janeiro: Paz e Terra, 1979.

HOMMA, A. K. O. História da agricultura na Amazônia: da era pré-colombiana ao terceiro milênio: Brasília: Embrapa Informação Tecnologia, 2003.

IANNI, O. A luta pela terra: história social da terra e da luta pela terra numa área da Amazônia. Petrópolis: Vozes, 1978. 
IBGE. Censo demográfico. Rio de Janeiro, 1991.

Contagem populacional. Rio de Janeiro, 1996.

Censo demográfico. Rio de Janeiro, 2000.

Produção agrícola municipal. Rio de Janeiro, 2003.

IDESP. Concórdia do Pará. Belém, 1990.

LAMARCHE, H. A agricultura familiar: comparação internacional. Campinas: Unicamp, 1993. v. 1.

MAUSS, M. Sociologia e Antropologia. São Paulo: EPU, 1974. v. 2

MENDRAS, H. Sociedades camponesas. Rio de Janeiro:Zahar, 1978.

MONZONI, M. Mudança climática: tomando posições. São Paulo: Amigos da Terra-Programa Amazônia, 2000.

OLIVEIRA, R. C. de. Identidade, etnia e estrutura social. São Paulo: Pioneira, 1976.

PETIT, P. Chão de promessas: elites políticas e transformações econômicas no estado do Pará pós-1964. Belém: Paka-Tatu, 2003.

POLLAK, M. Estudos históricos. Rio de Janeiro: Associação de Pesquisa e Documentação Histórica, v. 5, n. 10, 1990.

RADCLIFFE-BROWN, A. R. In: MELATTI, J. C. (org.) Coleção Grandes Cientistas Sociais. São Paulo: Ática, 1995.

RAVENA-CAÑETE, V. Memória e herança da terra: a história de um grupo camponês do Nordeste Paraense - Concórdia do Pará. 2000. Dissertação (Mestrado em Antropologia Social) - Centro de Filosofia e Ciências Humanas, Universidade Federal do Pará, Belém, 2000a.

Terra e memória: um estudo de caso em um grupo amazônico - os "herdeiros" de Carlos Guimarães. Trilhas, Belém, v. 1, n. 2, p. 56-65, 2000 b.

Os colonos de Nova Redenção: estratégias de permanência e dinâmica do campo rural da região Guajarina do estado do Pará. Tese (Doutorado em Ciências Socioambientais) - Núcleo de Altos Estudos Amazônicos, Belém, 2005.

REDFIELD, R. The little community, peasant society and Culture. Chicago: University of Chicago Press, 1960. 
SANTOS, R. A. de O. História econômica da Amazônia: 1800-1920. São Paulo: T. A. Queiroz, 1980.

SCHLESINGER, W.H. Biogeochemistry: an analysis of global change. San Francisco: Academic Press, 1991.

SHANIN, T. Naturaleza y lógica de la economía campesina. Barcelona: Editorial Anagrama, 1976

SILVA, F. C.s da. Frentes pioneiras e camponeses no sul do Pará. 1982. Dissertação (Mestrado em Planejamento do Desenvolvimento) - Núcleo de Altos Estudos Amazônicos, Universidade Federal do Pará, Belém, 1982.

SOLARI, A. O objeto da sociologia rural. In: SZMERCSÁNYI, T.; QUEDA, O. (Orgs.) Vida rural e mudança social. São Paulo: Companhia Editora Nacional, 1979. p. 3-14.

VEIGA, J. E. da. Cidades imaginárias: o Brasil é menos urbano do que se calcula. Campinas: Autores Associados, 2002.

WANDERLEY, M. N. B. Raízes históricas do campesinato brasileiro. In: ENCONTRO ANUAL DA ANPOCS, 20. GT 17: Processos Sociais Agrários. 1996. Caxambu. Anais... Caxambu: ANPOCS, 1996.

A ruralidade no Brasil moderno. Por um pacto pelo desenvolvimento rural. In: GIARRACA, N.(Org.). Una nueva ruralidad en América Latina? Buenos Aires: Clasco, 2001a.

Urbanização e ruralidade: relações entre a pequena cidade e o mundo rural. Estudo preliminar sobre os pequenos municípios em Pernambuco. Recife: Fundação Joaquim Nabuco, 2001b.

WOLF, E. R. Sociedades camponesas. Rio de Janeiro: Zahar, 1970.

WOORTTMANN, E. Herdeiros, parentes e compadres. São Paulo;Brasília: Hucitec, 1995.

WOORT'TMANN, E.; WOORT'TMANN, K. O trabalho da terra: a lógica e a simbólica da lavoura camponesa. Brasília: Universidade de Brasília, 1997. 